\title{
Analysis Infiltration Waters in Various Forms of Irrigation Channels by Using Dual Reciprocity Boundary Element Method
}

\author{
Ana Nurhasanah', Muhammad Manaqib², Irma Fauziah ${ }^{3}$ \\ ${ }^{1}$ UIN Syarif Hidayatullah Jakarta, ana.nurhasanah14@mhs.uinjkt.ac.id \\ ${ }^{2}$ UIN Syarif Hidayatullah Jakarta, muhammad.manaqib@uinjkt.ac.id \\ ${ }^{3}$ UIN Syarif Hidayatullah Jakarta, irma.fauziah@uinjkt.ac.id
}

doi: https://doi.org/10.15642/mantik.2020.6.1.52-65

\begin{abstract}
Abstrak: Penelitian ini membahas tentang infiltrasi saluran irigasi alur dalam berbagai bentuk saluran irigasi pada jenis tanah homogen. Model Matematika untuk masalah infiltrasi adalah Persamaan Richard. Persamaan Richard ini kemudian ditransformasikan dengan menggunakan transformasi Kirchhoff dan variabel tak berdimensi menjadi persamaan Helmholtz termodifikasi. Selanjutnya dengan menggunakan Dual Reciprocity Boundary Element Method (DRBEM), solusi numerik dari Persamaan Helmholtz termodifikasi diperoleh. Metode tersebut digunakan untuk menyelesaikan masalah infiltrasi pada saluran flat, non-flat tanpa impermeable dan non-flat dengan impermeable. Nilai daya serap dan kadungan air yang paling besar terletak di bawah permukaan saluran. Urutan bentuk saluran berdasarkan kandungan air yang paling banyak berturut-turut adalah non-flat channel tanpa impermeable, non-flat channel dengan impermeable dan saluran flat pada jenis tanah Lakish Clay.
\end{abstract}

Kata kunci: Infiltrasi; Saluran periodik, DRBEM.

\begin{abstract}
This research discusses the infiltration of furrow irrigation invarious forms of irrigation channels in homogeneous soils. The governing equation of the problems is a Richard's Equation. This equation is transformed using a set of transformation including Kirchhoff and dimensionless variables into Helmholtz modified equations. Furthermore with Dual Reciprocity Boundary Element Method (DRBEM), numerical solution of modified Helmholtz equation obtained. The proposed method is tested on problem involved infiltration from periodic flat channels, non-flat channels without impermeable and non-flat channels with impermeable. The greatest value of suction potential and water content is located below the channel surface. The most water consecutively is a non-flat channel without impermeable, non-flat channel with impermeable and flat channel on Lakish Clay soils.
\end{abstract}

Keywords: Infiltration; Periodic channels, DRBEM.

How to cite: A. Nurhasanah, M. Manaqib, and I. Fauziah, "Analysis Infiltration Waters in Various Forms of Irrigation Channels by Using Dual Reciprocity Boundary Element Method", J. Mat. Mantik, vol. 6, no. 1, pp. 


\section{Introduction}

Water access for using productivity such as agriculture and family business are very important to create livelihood opportunity, generate income, and contribute towards economical productivity. Almost fifth of world population, along half billion people live at the place which encounter physical water crisis [1]. Water availability originated of surface, water in the soil and source, which is year by year tend to decrease as result of environmental damage. On the other hand, water necessary time by time becomes increase as the result of increase in population and industrial growth [2]. Water function in agriculture generally as irrigation or watering to fulfill plant needs, without good irrigation that the result of plant which managed by farmers will not achieve maximum result. Regular water supply is expected can help the soil to tend water content stability as of infiltration process.

One approach to find and explain solutions to problems that occur in the real world is by mathematical modeling. After the mathematical model is obtained it can be solved mathematically and can be reapplied in real problems [3]. Along with the development of science, a lot of mathematical model has been done relating to infiltration in irrigation channels. One of them is research of I. Solekhudin and K.C. Ang [4], namely for irrigation channels in the form of flat, rectangular, semi-circular, and trapezoidal. Mathematical models of water infiltration problems in channel irrigation channels are in the form of boundary conditions with a governing equation in the form of a modified Helmholtz equation with the Robin boundary conditions. One approach to solving the problem this time is to be able to use the Dual Reciprocity Boundary Element Method (DRBEM) numerical method. DRBEM is a part or development of the Boundary Element Method (BEM). BEM is a numerical method used to solve partial differential equations found in mathematical physics and engineering. Such as Laplace's Equation, Helmholtz's Equation, Diffusion Convection Equation, Potential and Viscous Flow Equations, Electrostatic and Electromagnetic Equations, and Elastostatics and Elestodynamic Linear Equations [5].

There are several advantages of the Boundary Element Method (BEM) compared to other numerical methods, such as the Finite Element Method (FEM) and the Finite Difference Method (FDM). Here are some of the advantages [6].

- Discretization is only done at the domain boundary, thus making numerical modeling with BEM simple and reducing the number of collocation points needed.

- Modified BEM can solve problems with unlimited domains.

- MEB is proven effective in calculating derivatives from field functions such as flux, voltage, pressure, and moment. MEB can also resolve the concentration of forces and moments in the domain interior and domain boundaries.

- Using a set of collocation points located at the domain boundaries can be used to find solutions at all points in the domain. In contrast to FEM and FDM the solution is obtained only at the collocation point.

- BEM can also solve problems with complicated domains, such as a crack.

This research will discuss about the solution to the problem of water infiltration in various forms of furrow irrigation channels using the Dual Reciprocity Boundary Element Method, to determine the characteristics of infiltration and the distribution characteristics of the water in the form of Flat Channel, Non-Flat Channel without Impermeable (Rectangular Channel, Semi-circular Channel, Trapezoidal Channel), and Non-Flat Channel with Impermeable (Rectangular Channel, Trapezoidal Channel) [7]. 


\section{Methods}

The steps to solve the boundary condition problem of the Helmholtz equation with the Dual Reciprocity Boundary Element Method (DRBEM) are [8]:

- Reciprocal Relation

Reciprocal relation between the fundamental solution of the Laplace equation and the solution of the Helmholtz equation in the $R$.

$$
\int_{C}\left(\Phi \frac{\partial \phi}{\partial n}-\phi \frac{\partial \Phi}{\partial n}\right) d s=\iint_{R} \Phi\left(g-k^{2} \phi\right) d x d y \text {. }
$$

- Boundary Integral Equations

The form of the boundary integral equation obtained from reciprocal relations and domain modifications.

$$
\begin{aligned}
\lambda(\xi, \eta) \phi(\xi, \eta)= & \int_{C}\left(\phi(x, y) \frac{\partial \Phi(x, y ; \xi, \eta)}{\partial n}-\Phi(x, y ; \xi, \eta) \frac{\partial \phi(x, y)}{\partial n}\right) d s \\
& +\iint_{R} \Phi(x, y ; \xi, \eta)\left(g(x, y)-k^{2} \phi(x, y)\right) d x d y
\end{aligned}
$$

with

$$
\lambda(\xi, \eta)=\left\{\begin{array}{l}
0, \text { if }(\xi, \eta) \notin R \cup C \\
\frac{1}{2}, \text { if }(\xi, \eta) \text { lies on a smooth of } C \\
1, \text { if }(\xi, \eta) \in R
\end{array}\right.
$$

- Domain Integral Approach

By using the radial basis function approach, an integral domain approach is obtained as follows.

$$
\begin{aligned}
\iint_{R} \Phi(x, y ; \xi, \eta)( & \left.g(x, y)-k^{2} \phi(x, y)\right) d x d y \\
= & \sum_{j=1}^{M}\left[\sum_{m=1}^{M} \omega\left(a^{(j)}, b^{(j)} ; a^{(m)}, b^{(m)}\right) \psi\left(\xi, \eta ; a^{(m)}, b^{(m)}\right)\right] \\
& {\left[g\left(a^{(j)}, b^{(j)}\right)-k^{2} \phi\left(a^{(j)}, b^{(j)}\right)\right] }
\end{aligned}
$$

- Boundary Integral Equations in the Form of Line Integral

$$
\begin{aligned}
& \lambda(\xi, \eta) \phi(\xi, \eta)=\sum_{j=1}^{M}\left[\sum_{m=1}^{M} \omega\left(a^{(j)}, b^{(j)} ; a^{(m)}, b^{(m)}\right) \psi\left(\xi, \eta ; a^{(m)}, b^{(m)}\right)\right] \\
& {\left[g\left(a^{(j)}, b^{(j)}\right)-k^{2} \phi\left(a^{(j)}, b^{(j)}\right)\right]+} \\
& \int_{C}\left(\phi(x, y) \frac{\partial \Phi(x, y ; \xi, \eta)}{\partial n}-\Phi(x, y ; \xi, \eta) \frac{\partial \phi(x, y)}{\partial n}\right) d s \\
& \text { for }(\xi, \eta) \in R \cup C .
\end{aligned}
$$

- Completion of Boundary Integral Equations

Substitute the collocation points to the boundary integral equation obtained by linear system.

$\lambda\left(\bar{x}^{(n)}, \bar{y}^{(n)}\right) \phi\left(\bar{x}^{(n)}, \bar{y}^{(n)}\right)=\sum_{j=1}^{N+L} \mu^{(n j)}\left[g\left(\bar{x}^{(j)}, \bar{y}^{(j)}\right)-k^{2} \phi\left(\bar{x}^{(j)}, \bar{y}^{(j)}\right)\right]+$ 


$$
\sum_{k=1}^{N}\left[\bar{\phi}^{(k)} f_{2}^{(k)}\left(\bar{x}^{(n)}, \bar{y}^{(n)}\right)-\bar{p}^{(k)} f_{1}^{(k)}\left(\bar{x}^{(n)}, \bar{y}^{(n)}\right)\right]
$$

for $n=1,2, \ldots, N+L$

with

$$
\begin{aligned}
\mu^{(n j)} & =\sum_{m=1}^{N+L} \omega\left(\bar{x}^{(j)}, \bar{y}^{(j)} ; \bar{x}^{(m)}, \bar{y}^{(m)}\right) \psi\left(\xi, \eta ; \bar{x}^{(m)}, \bar{y}^{(m)}\right) \\
f_{1}^{(k)}\left(\bar{x}^{(n)}, \bar{y}^{(n)}\right) & =\frac{1}{4 \pi} \int_{C^{(k)}} \ln \left(\left(x-\bar{x}^{(n)}\right)^{2}+\left(y-\bar{y}^{(n)}\right)^{2}\right) d s \\
f_{2}^{(k)}\left(\bar{x}^{(n)}, \bar{y}^{(n)}\right) & =\frac{1}{4 \pi} \int_{C^{(k)}} \frac{\partial}{\partial n}\left[\ln \left(\left(x-\bar{x}^{(n)}\right)^{2}+\left(y-\bar{y}^{(n)}\right)^{2}\right)\right] d s .
\end{aligned}
$$

- Complete the linear system. Next, by substituting the linear system solution into the boundary integral equation, an equation can be obtained that can be used to evaluate the partial differential equation solution at all points in the domain.

\section{Result and Discussion}

\subsection{Problem Formulation}

This study uses DRBEM to solve water infiltration problems in various furrow irrigation channels on Lakish Clay soil types with $\alpha\left(\mathrm{cm}^{-1}\right)=1.38 \times 10^{-2}$, $K_{0}(\mathrm{~cm} / \mathrm{s})=8.1 \times 10^{-5} \theta_{r}=0.068, \theta_{s}=0.38$ and $n=1.09$ of [9] and [10]. The forms of channel irrigation that were studied were Flat Channel, Non-Flat Channel without impermeable (Rectangular Channel, Trapezoidal Channel, Semi-Circular Channel), and Non-Flat Channel with impermeable (Rectangular Channel, Trapezoidal Channel). The assumptions used on each channel are:

- The width of the irrigation channel has the same width and has a long enough length, so in this model the length of the irrigation channel is ignored.

- Irrigation channels in the form of Flat Channel, Non-Flat Channel without impermeable (Rectangular Channel, Trapezoidal Channel, Semi-Circular Channel), and Non-Flat Channel with impermeable (Rectangular Channel, Trapezoidal Channel).

- The distance between the midpoints of two adjacent channels is $2(L+D)$.

- The channel is always full of water.

- The influence of other irrigation channels is ignored.

- The infiltration rate of water / large incoming fluxes on the surface of the irrigation channel is constant, which is equal to $v_{0}$.

There is no incoming water flow except from the channel.

\subsection{Mathematical Models of Infiltration in Various Forms of Irrigation Channels}

Mathematical model of water infiltration in channel irrigation channels in the form of Problem Boundary Conditions (MSB) with the condition of a Neumann and Robin boundary. While the governing equation is in the form of a modified Helmholtz equation 
[11]. The equation governing the mathematical model of water infiltration comes from Richard's equation [11].

$$
\begin{aligned}
\frac{\partial \theta}{\partial T} & =-\nabla\left(-K(\theta)\left[\frac{\partial \psi}{\partial X} i+\left(\frac{\partial \psi}{\partial Z}-1\right) j\right]\right) \\
& =\frac{\partial}{\partial X}\left(K(\theta) \frac{\partial \psi}{\partial X}\right)+\frac{\partial}{\partial Z}\left(K(\theta)\left(\frac{\partial \psi}{\partial Z}-1\right)\right) \\
& =\frac{\partial}{\partial X}\left(K(\theta) \frac{\partial \psi}{\partial X}\right)+\frac{\partial}{\partial Z}\left(K(\theta) \frac{\partial \psi}{\partial Z}\right)-\frac{\partial K(\theta)}{\partial Z}
\end{aligned}
$$

Richard's equation will be transformed into the Helmholtz equation in the form of a linear differential equation.

- Kirchhoff's transformation uses the formula

$$
\Theta=\int_{-\infty}^{\psi} K(s) d s
$$

- An exponential model of hydraulic conductivity is defined

$K=K_{0} e^{\alpha \psi}, \alpha>0$.

- Transform to the form of the dimensionless variable equation so that it is obtained:

$x=\frac{\alpha}{2} X, z=\frac{\alpha}{2} Z, \Phi=\frac{\pi \Theta}{v_{0} L}, u=\frac{2 \pi}{v_{0} \alpha L} U, v=\frac{2 \pi}{v_{0} \alpha L} V, f=\frac{2 \pi}{v_{0} \alpha L} F$.

So, we find

$$
\frac{\partial^{2} \phi}{\partial^{2} x}+\frac{\partial^{2} \phi}{\partial^{2} z}=\phi
$$

as a governing equation of mathematical models of water infiltration which includes the Modified Helmholtz equation.

This research will discuss about the solution to the problem of water infiltration in various forms of channel irrigation channels by using the Dual Reciprocity Boundary Element Method, to determine the characteristics of infiltration and the distribution characteristics of the water in the form of Flat Channel, Non-Flat Channel without Impermeable (Rectangular Channel, Semi-circular Channel, Trapezoidal Channel), and Non-Flat Channel with Impermeable (Rectangular Channel, Trapezoidal Channel), as shown in the Figure 1. 


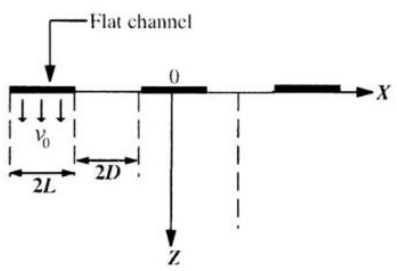

(a) Flat Channel

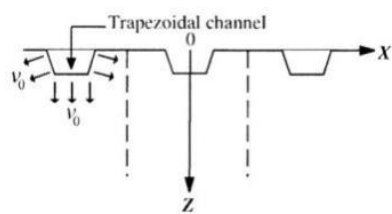

(d) Trapezoidal Channel

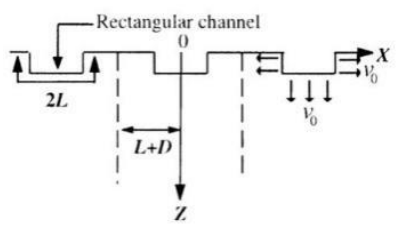

(b) Rectangular Channel

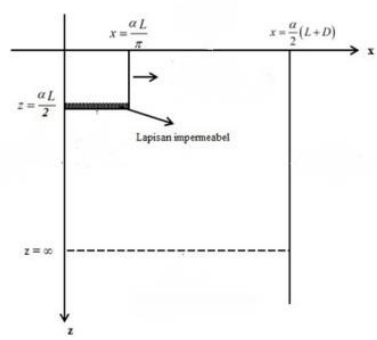

(e) Rectangular with Impermeable

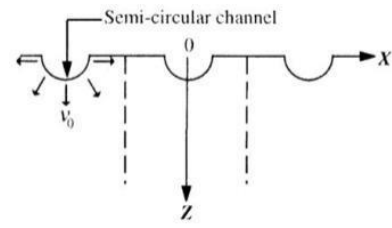

(c) Semi-Circular Channel

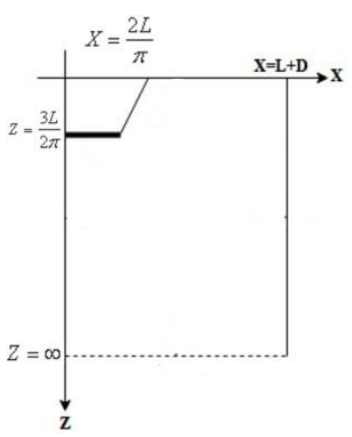

(f) Trapezoidal with Impermeable

Figure 1. Geometry of Furrow Irrigation Channels[4]

Furthermore, based on the shape of the channel and the assumptions about irrigation channels, the boundary conditions for the mathematical model of water infiltration on the channel irrigation can be obtained as follows [12] [13][14].

- Flat Channel

$$
\begin{array}{ll}
\frac{\partial \phi}{\partial n}=\frac{2 \pi}{\alpha L}-\phi & , \text { for } 0 \leq x \leq \frac{\alpha}{2} L \text { and } z=0 \\
\frac{\partial \phi}{\partial n}=-\phi & , \text { for } \frac{\alpha}{2} L \leq x \leq \frac{\alpha}{2}(L+D) \text { and } z=0 \\
\frac{\partial \phi}{\partial n}=0 & , \text { for } x=0 \text { and } z \geq 0 \\
\frac{\partial \phi}{\partial n}=0 & , \text { for } x=\frac{\alpha}{2}(L+D) \text { and } z \geq 0 \\
\frac{\partial \phi}{\partial n}=-\phi & \text {,for } 0 \leq \frac{2}{\alpha} x \leq L+D \text { and } z=\infty
\end{array}
$$

- Non-Flat Channel without Impermeable

$$
\begin{array}{ll}
\frac{\partial \phi}{\partial n}=\frac{2 \pi}{\alpha L} e^{-z}-\phi n_{2} & \text {, on the surface of the channel } \\
\frac{\partial \phi}{\partial n}=-\phi & \text {, on the surface of the soil outside the channels } \\
\frac{\partial \phi}{\partial n}=0 & \text {, towards } x=0 \text { and } z \geq 0 \\
\frac{\partial \phi}{\partial n}=0 & \text {,towards } x=\frac{\alpha}{2}(L+D) \text { and } z \geq 0 \\
\frac{\partial \phi}{\partial n}=-\phi & \text {,towards } 0 \leq \frac{2}{\alpha} x \leq L+D \text { and } z=\infty
\end{array}
$$


- Non-Flat Channel with Impermeable

$$
\begin{array}{ll}
\frac{\partial \phi}{\partial n}=\frac{2 \pi}{\alpha L} e^{-z}-\phi n_{2} & , \text { on the surface permeable channel } \\
\frac{\partial \phi}{\partial n}=\phi n_{2} & \text {, on the surface impermeable channel } \\
\frac{\partial \phi}{\partial n}=-\phi & \text {,on the surface of the soil outside the channels } \\
\frac{\partial \phi}{\partial n}=0 & \text {,towards } x=0 \text { and } z \geq 0 \\
\frac{\partial \phi}{\partial n}=0 & \text {,towards } x=\frac{\alpha}{2}(L+D) \text { and } z \geq 0 \\
\frac{\partial \phi}{\partial n}=-\phi & \text { towards } 0 \leq \frac{2}{\alpha} x \leq L+D \text { and } z=\infty
\end{array}
$$

\subsection{Settlement with DRBEM}

Mathematical model of water infiltration in channel irrigation in the form of a modified Helmholtz equation with boundary conditions of each channel shape. The model will be completed using DRBEM. The main step in solving the use of DRBEM is to form a linear system. However, before the step is conducted, the boundary integral equation needs to be formed. Substitute boundary conditions to the integral equation of the Helmholtz equation. After the boundary integral equations are obtained, a linear system can be formed by discretizing domain boundaries into a number of line segments and selecting a number of interior points. Then the linear is converted into the $\mathrm{Ax}=\mathrm{b}$ matrix equation with $x$ is a column vector containing unknown variables.

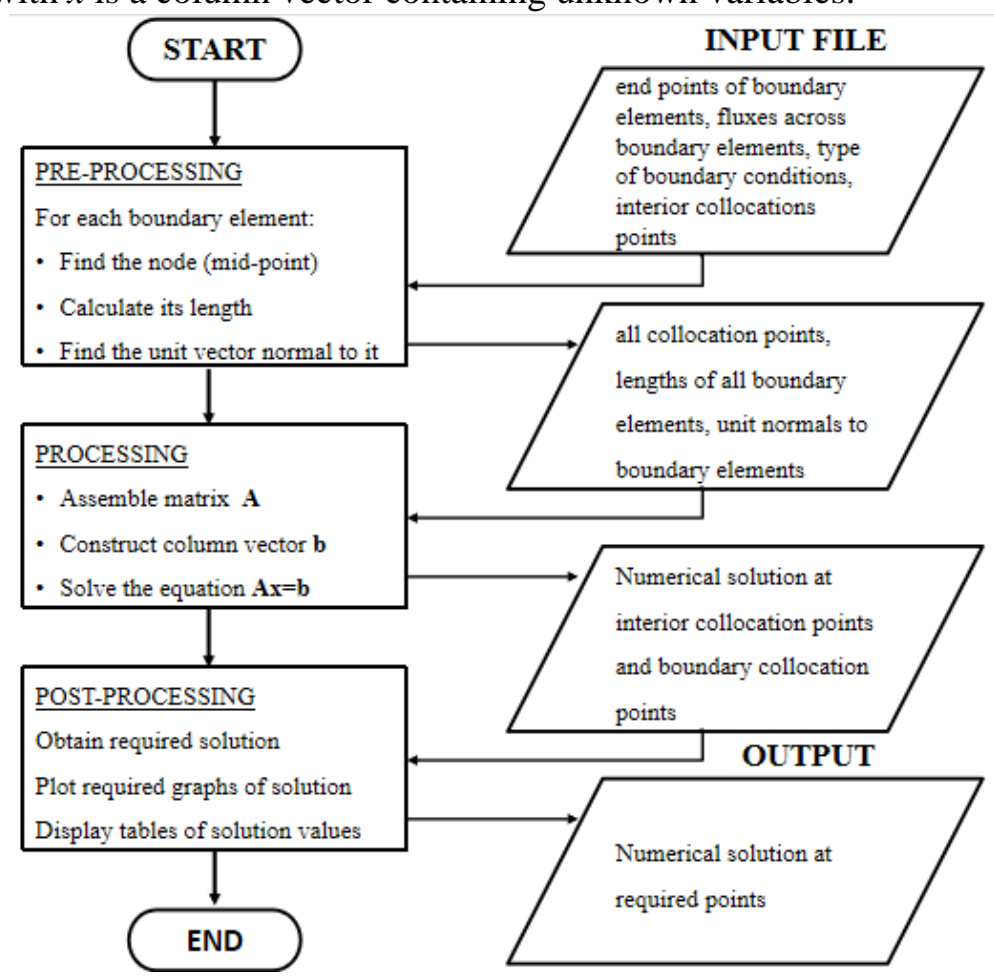

Figure 1. Schematic representation of the program to implement the DRBEM [15] 
The Matlab implementation in this case is divided into three stages, namely the ones named Pre-Processing, Processing, and Post-Processing, as shown in Figure (2). After the Matlab program implementation is complete, it is then used to solve the infiltration problem in various types of channels in one type of soil namely Lakish Clay. Next, choose $N=200$, i.e. the number of line segments for discretizing domain boundaries. $N=200$ because the accuracy of the resulting numerical approach is quite good [15]. $M$ values for each type of channel are different because the size of the dimensionless domain of each channel type is different depending on the shape of the channel. Flat Channel given $M=625$, Trapezoidal Channel given $M=619$, Rectangular Channel given $M=625$, Semi-Circular Channel given $M=593$, Trapezoidal Channel with Impermeable given $M=619$, Rectangular Channel with Impermeable given $M=625$.

Each type of channel will evaluate the values of $\psi$ and $\theta$ in some values at several points along the line $X=10 \mathrm{~cm}, X=30 \mathrm{~cm}, X=50 \mathrm{~cm}, X=70 \mathrm{~cm}, X=90 \mathrm{~cm}$, for $0 \leq Z \leq 200 \mathrm{~cm}$.

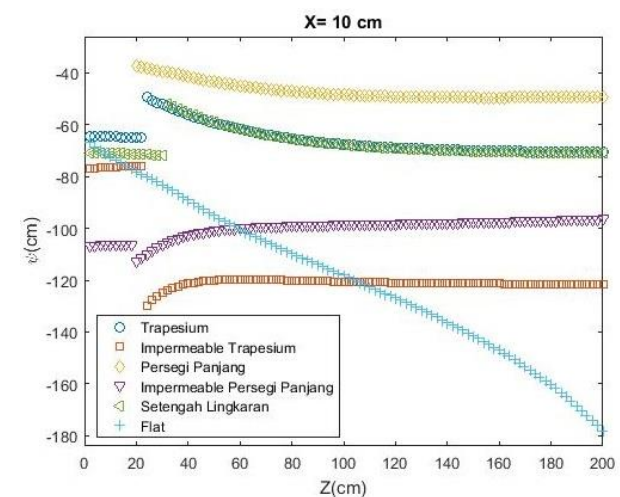

(a) Suction Potential $(\boldsymbol{\Psi})$

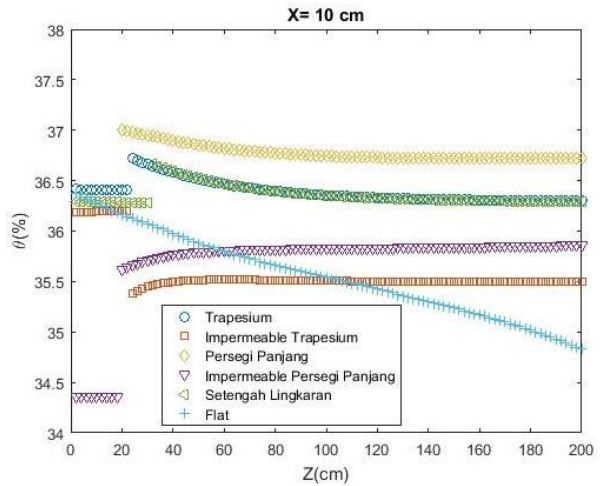

(b) Water Content $(\boldsymbol{\theta})$

Figure 2. Suction Potential and Water Content toward $\boldsymbol{X}=\mathbf{1 0}$

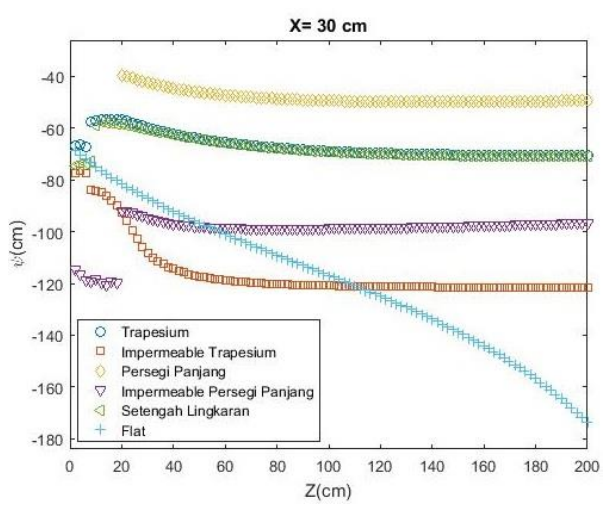

(a) Suction Potential $(\boldsymbol{\psi})$

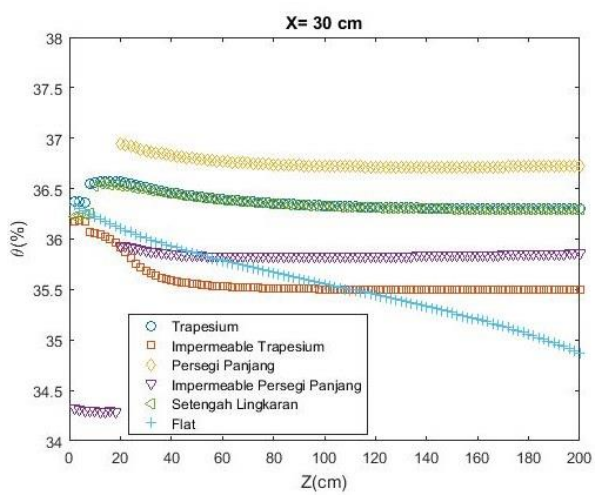

(b) Water Content $(\boldsymbol{\theta})$

Figure 3. Suction Potential dan Water Content toward $\boldsymbol{X}=\mathbf{3 0}$

It is shown that Figure 3 is a graph of values $\psi$ and $\theta$ below the channel. The graphs $\psi$ and $\theta$ are broken because there are points evaluated in the channel, so the graphs $\psi$ and $\theta$ in the channel can be ignored. Value of $\psi$ and $\theta$ flat channel and non-flat without impermeable decreases with increasing depth and goes to the point of convergence. As for non-flat channels with impermeable values $\psi$ and $\theta$ increase with increasing soil depth to the point of convergence due to impermeable layers in the channel. 
Based on Figure 4, the graphs $\psi$ and $\theta$ are broken because there are points that are evaluated in the channel, so the graphs $\psi$ and $\theta$ in the channel can be ignored. Values $\psi$ and $\theta$ at $\mathrm{X}=30$ go up at a certain depth and go down at a certain depth to the point of convergence. It was concluded that the value of $\psi$ in the shallow position is greater than in the deep position. This is in accordance with the assumption that water enters from the channel and then water seeps into the lower and deeper soil below the channel.

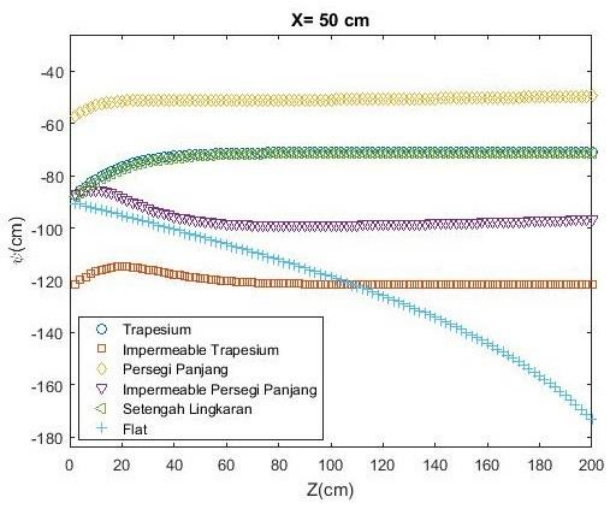

(a) Suction Potential $(\boldsymbol{\Psi})$

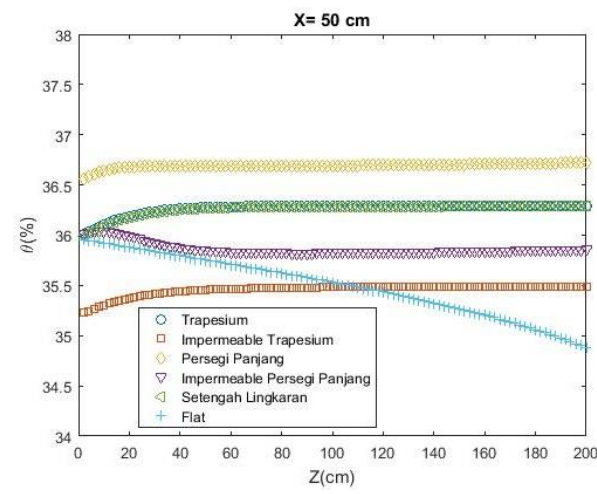

(b) Water Content $(\boldsymbol{\theta})$

Figure 4. Suction Potential and Water Content torward $\boldsymbol{X}=\mathbf{5 0}$

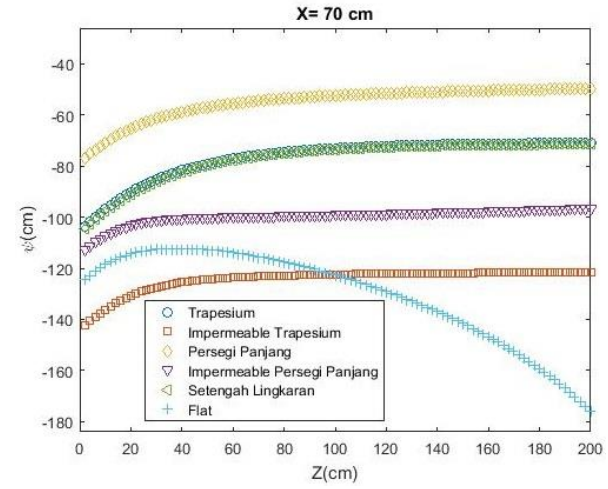

(a) Suction Potential $(\boldsymbol{\psi})$

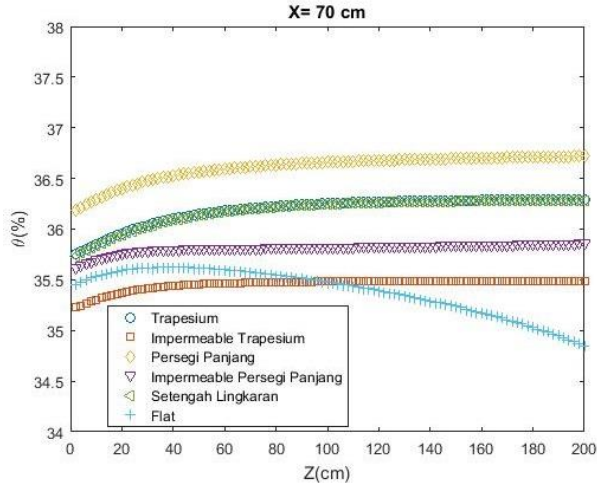

(b) Water Content $(\boldsymbol{\theta})$

Figure 5. Suction Potential and Water Content toward $\boldsymbol{X}=\mathbf{7 0}$

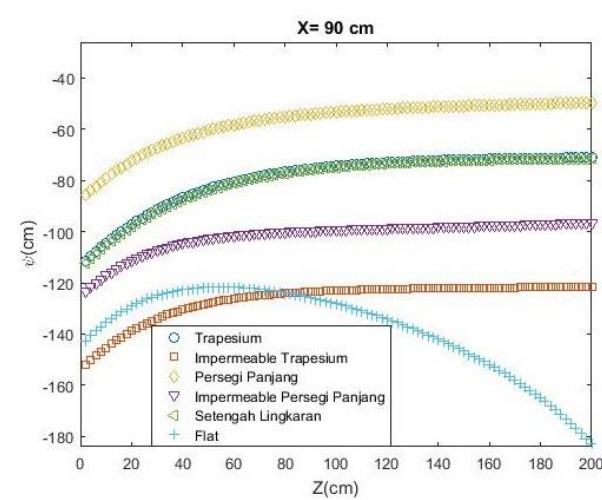

(a) Suction Potential $(\boldsymbol{\psi})$

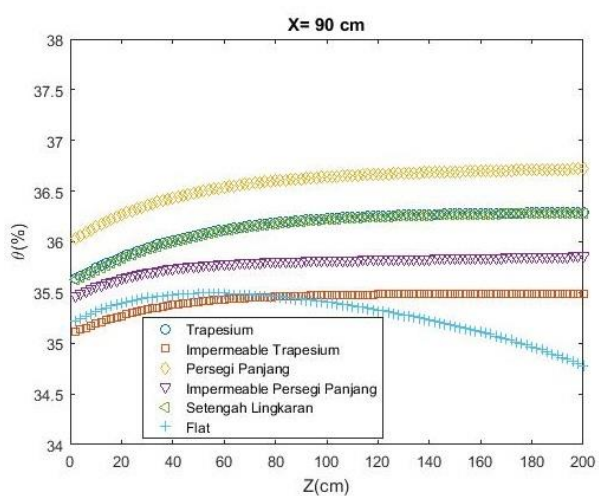

(b) Water Content $(\boldsymbol{\theta})$

Figure 6. Suction Potential and Water Content toward $\boldsymbol{X}=\mathbf{9 0}$

Based on Figures 5, Figure 6, and Figure 7 it is clear that the values of $\psi$ and $\theta$ along these lines are values of $\psi$ and $\theta$ not below the surface of the channel. The values of $\psi$ and $\theta$ in the flat channel decrease at a certain depth and non-flat without impermeable increases with increasing depth and go to the point of convergence. As for non-flat channels with 
impermeable values $\psi$ and $\theta$ rise to a certain depth to the point of convergence due to the impermeable layer on the channel. The value of $\psi$ is directly proportional to the value of $\theta$. However, the pattern of relationships for each type of channel is different, seen from different curves for each type of channel. The value of $\theta$ which increases with increasing depth indicates that the shallow water content is smaller than the deep position for the soil which is not below the surface of the canal. This is consistent with the assumption that no flow of water enters the ground surface.

Based on Figure 3 to Figure 7 there is no significant difference in each type of nonflat channel, but there is a remarkable difference in the flat channel with other channels, especially at ground level. The values of $\psi$ and $\theta$ always decrease when away from the center of the channel surface. Next to see the distribution pattern of the value of suction potential $(\psi)$ and water content $(\theta)$ in the domain of each channel type. In this case the domain is a cross section of a channel on the ground with a width of $100 \mathrm{~cm}$ and a depth of $200 \mathrm{~cm}$. The following is given Figure 8 to Figure 10 which are consecutive Flat Channel, Rectangular Channel, Semi-Circular Channel, Trapezoidal Channel, Trapezoidal with Impermeable and Rectangular with Impermeable. The image on the left is the distribution of suction potential values $(\psi)$ and the image on the right is the distribution of the value of water content $(\theta)$.

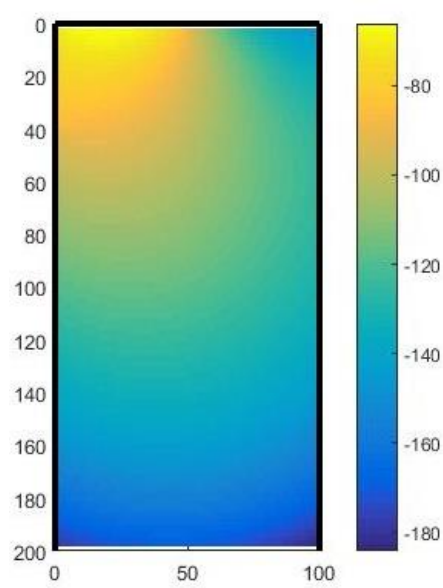

(a) Suction Potential ( $\boldsymbol{\psi})$

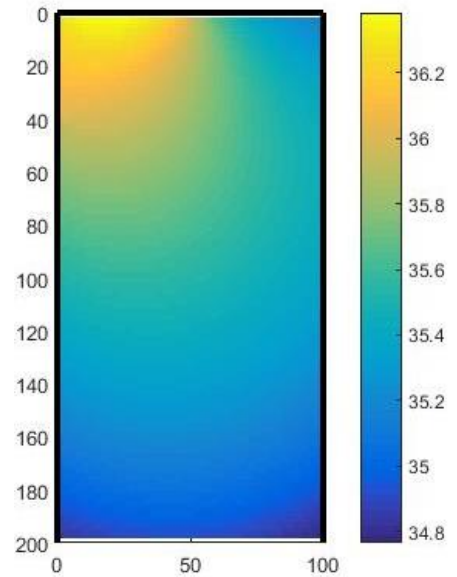

(b) Water Content $(\boldsymbol{\theta})$

Figure 7. Water Distribution Pattern on the Flat Channel

Based on Figure 8 on the flat channel, it appears that the value of the greatest suction potential lies below the channel, the deeper the ground level the smaller the suction potential value. Likewise, the value of the largest water content is located under the channel, the further from the center of the channel the smaller the value of water content. 


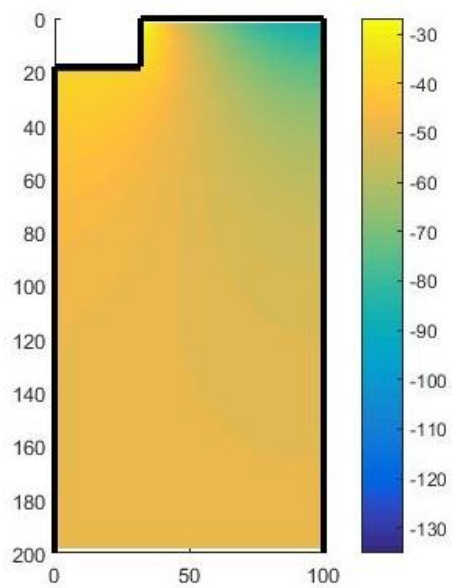

(a) Suction Potential $(\boldsymbol{\psi})$

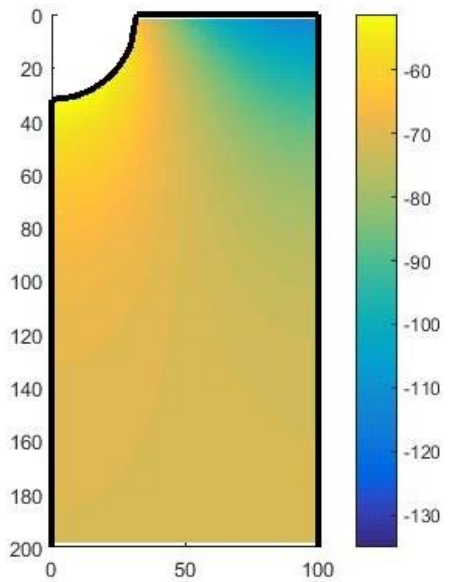

(a) Suction Potential ( $\boldsymbol{\Psi})$

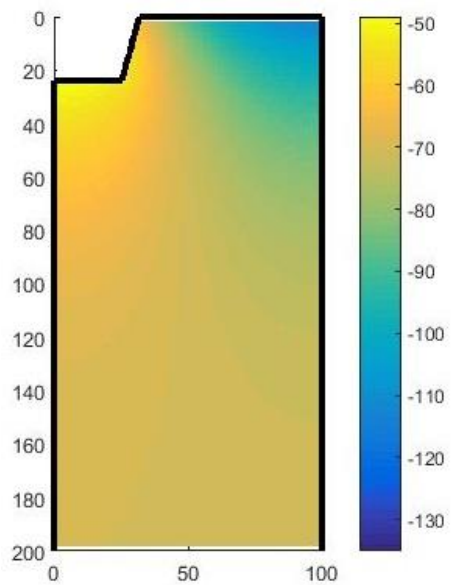

(a) Suction Potential ( $\boldsymbol{\Psi})$

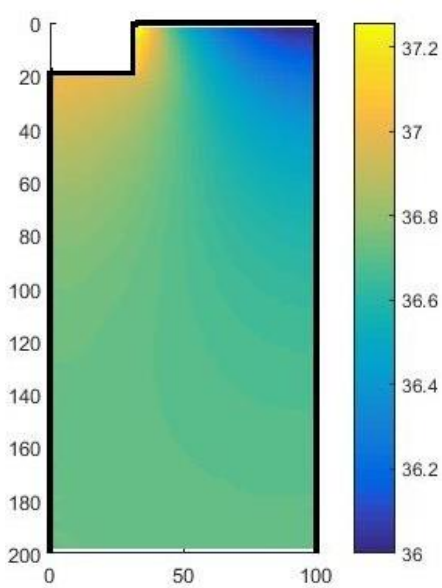

(b) Water Content ( $\boldsymbol{\theta})$

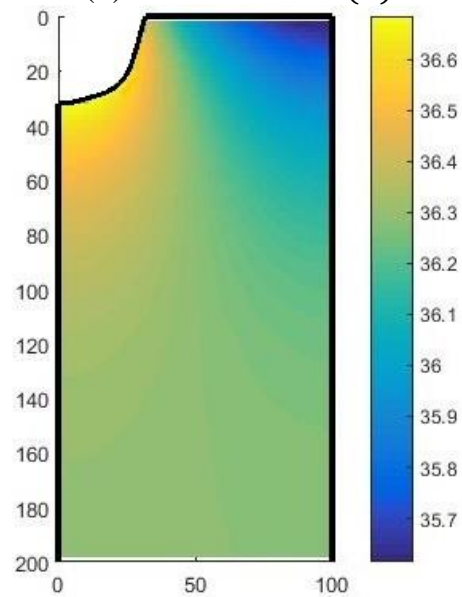

(b) Water Content $(\boldsymbol{\theta})$

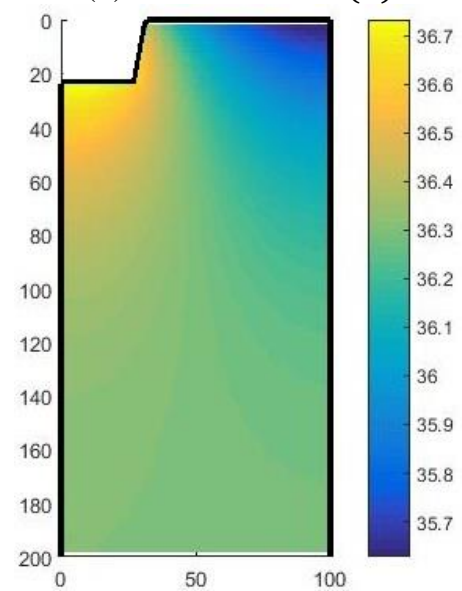

(b) Water Content $(\boldsymbol{\theta})$

Figure 8. Water Distribution Pattern on Non-Flat Channel without Impermeable

Based on Figure 9 on a non-flat channel consisting of rectangular, circular, and trapezoidal channels. It can be seen that the value of the suction potential spreads evenly below the channel, the closer to the center of the channel the greater the value of the suction potential. You can also see the value of the water content is spread but not flat, the greatest value of water content is located below the channel. 


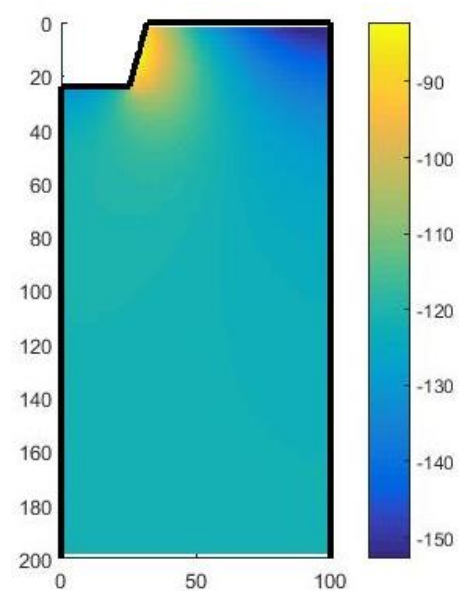

(a) Suction Potential $(\boldsymbol{\Psi})$

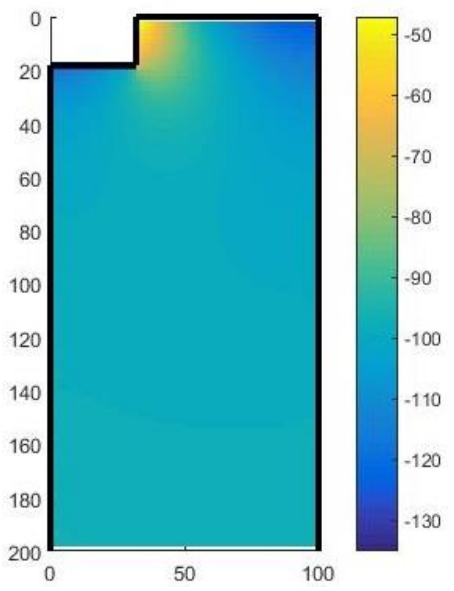

(a) Suction Potential $(\boldsymbol{\Psi})$

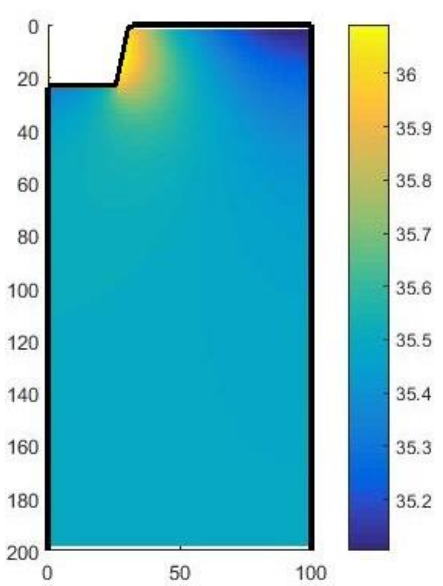

(b) Water Content ( $\boldsymbol{\theta})$

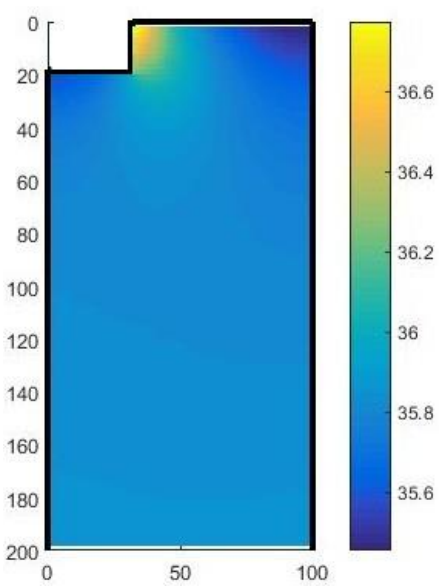

(b) Water Content $(\boldsymbol{\theta})$

Figure 9. Water Distribution Pattern on Non-Flat Channel with Impermeable

Based on Figure 10 on a non-flat channel with Impermeable. It can be seen that the value of the greatest suction potential is located on the wall of the channel that is not closed, the closer to the center of the channel, the greater the value of suction potential. Likewise, with the value of its water content, the largest value of water content is located on the wall of the channel that is not closed.

The distribution pattern of suction potential and water content values is seen from the surface plot of the suction potential and water content values in the domain. Based on Figure 8 to Figure 10 it can be seen that the greatest suction potential is located below the channel, while the smallest is at the ground surface which is far from the center of the channel. In addition, it can be seen that in the upper soil layers the farther away from the center of the channel the smaller the value of water content.

\section{Conclusions}

DRBEM can solve the problem of water infiltration in the channel irrigation channel in the form of boundary conditions with the governing equation is the modified Helmholtz equation. The greatest Suction Potential and Water Content values are located below the surface of the channel, and the smallest Suction Potential and Water Content values are located far from the center point of the channel. Suction Potential value is directly proportional to the value of Water Content, the more waterpower is absorbed, the more 
water content in the soil. Channel sequences based on the water content that are most numerous are Rectangular Channel, Trapezoidal Channel, Semi-Circular Channel, Rectangular Channel with Impermeable, Trapezoidal Channel with Impermeable, and Flat Channel. In addition, it can be concluded that the form of non-Flat Channel channels without Impermeable has more water content in the Lakish Clay soil type.

This study uses DRBEM to complete channel irrigation channel infiltration in various types of canals on Lakish Clay soil types without adding plant elements. Future studies can add plant elements to agricultural land with different soil types and complete the irrigation of time-dependent channel irrigation channels.

\section{References}

[1] UN World Water Assessment Programme, The United Nations World Water Development Report 2015. UNESCO, 2015.

[2] M. G. Bos, R.A.L. Kselik, R. Allen, and D. Molden, "Water Requirements for Irrigation and the Environment", 2009, doi: 10.1007/978-1-4020-8948-0.

[3] M. Manaqib, I. Fauziah, and M. Mujiyanti, "Mathematical Model for MERS-COV Disease Transmission with Medical Mask Usage and Vaccination", Inprime: Indonesian Journal of Pure and Applied Mathematics, vol. 1, no. 2, pp. 97-109, 2019. doi: 10.15408/inprime.v1i2.13553

[4] I. Solekhudin and K.C. Ang, "A dual-reciprocity boundary element method for steady infiltration problems", ANZIAM Journal, vol. 54, pp. 171-180, 2013. doi: 10.21914/anziamj.v54i0.5699

[5] C. Pozrikidis, A Practical Guide to Boundary Element Method with The Software Library BEMLIB. Florida: Chapman and Hall/CRR, 2002.

[6] J. T. Katsikadelis, Boundary Element: Theory and Application. Oxford: Elsevier, 2002.

[7] M. I. Azis, D. L. Clements, and M. Lobo, "A Boundary Elements Method for Steady Infiltration from Periodic Channels", ANZIAM Journal, vol. 44, pp. C61-C78, 2003. doi: https://doi.org/10.21914/anziamj.v44i0.672.

[8] M. Manaqib and I. Solekhudin, "Dual Reciprocity Boundary Element Method untuk Menyelesaikan Masalah Infiltrasi Air pada Saluran Irigasi Alur," in Seminar Matematika dan Pendidikan Matematika UNY, Yogyakarta, 2017.

[9] E. Bresler, "Analysis of Trickle Irrigation with Application to Design Problems", Irrigation Science, vol. 1, pp. 3-17, 1978.

[10] A. W. Warrick, Soil Physics Companion. Washington D.C.: CRC Press, 2002.

[11] M. Manaqib., "Pemodelan Matematika Infiltrasi Air pada Saluran Irigasi Alur", J. Mat. Mantik, vol. 3, no. 1, pp. 23-29, Oct. 2017.

[12] V. Batu, "Steady Infiltration from Single and Periodic Strip Sources", Soil Science Society of America Journal, Vol. 42, pp. 544-549, 1978. doi:10.2136/sssaj1978.03615995004200040002x

[13] M. Lobo, D. L. Clements, and N. Widana, "Infiltration from Irrigation Channels in a Soil with Impermeable Inclusions," ANZIAM Journal, vol. 46, pp. C1055-C1068, 2005.

[14] D. L. Clements, M. Lobo, and N. Widana, "A Hypersingular Boundary Integral Equation for a Class of a Problems Concerning Infiltration from Periodic Channels", Electronic Journal of Boundary Element, vol. 5, no. 1, pp. 1-16, 2007. doi: https://doi.org/10.14713/ejbe.v5i1.779. 
A. Nurhasanah, M. Manaqib, and I. Fauziah Analysis Infiltration Waters in Various Forms of Irrigation Channels by Using Dual Reciprocity Boundary

[15] I. Solekhudin and K.C. Ang, "Suction Potential and Water Absorption from Periodic Channels in Different Types of Homogeneous Soils," Electronic Jurnal of Boundary Element, vol. 10, no. 2, pp. 42-55, 2012. 